BIOTROPIA NO. 19, $2002: 57-64$

\title{
MOLECULAR IDENTIFICATION OF EGG PARASITOID, TELENOMUS SPP. (HYMENOPTERA: SCELIONIDAE) FROM SEVERAL LOCATIONS IN JAVA USING RAPD -PCR
}

\author{
NETTI YULIARTI ${ }^{1}$, PURNAMA HIDAYAT ${ }^{2}$, AND DAMAYANTI BUCHORI ${ }^{3}$ \\ 'Agricultural Polytechnic, Andalas University, Payakumbuh, West Sumatera, Indonesia \\ ${ }^{\mathrm{MJ}}$ Department of Plant Pests and Diseases, Faculty of Agriculture, Bogor Agricultural \\ University, Bogor, Indonesia
}

\begin{abstract}
Random amplified polymorphic DNA (RAPD) amplified by the polymerase chain reaction (PCR) was used to determine the differences of four Telenomus species and five populations of $T$. rowani from several locations in Java. Amplification of genomic DNA by using primer P2 (Amersham Pharmacia Biotech) indicated that each Telenomus species had a unique set of RAPD bands. Two bands which characterized the genus are estimated to be 300 and 430 bp. Each species had three specific bright bands except $T$. dignoides which only had two specific bright bands. However, no bands are unique to any of the five populations of $T$. rowani and all of the bands are less than 500 base-pair. Cluster analysis using UPGMA (Unweighed Pair Group Method With Arithmatic Mean) showed that the four Telenomus species consist of two groups, $T$. rowani and $T$. remus in one cluster and $T$. dignus with $T$. dignoides belonging to another cluster.
\end{abstract}

Key words : PCR-RAPD / clustering / Telenomus spp.

\section{INTRODUCTION}

Telenomus (Hymenoptera: Scelionidae) are minute wasps, often black, about $1 \mathrm{~mm}$ in length, and feed exclusively on the eggs of other insects. The genus particularly attacks Lepidoptera and Hemiptera but they are also known to attack Diptera and Neuroptera (Johnson 1984). The host range is relatively broad but the degree of host-specificity varies between species (Polaszek \& Kimani 1990).

Telenomus often plays an important role in the natural control of insect pest populations. Some biological control programs are presently being carried out on pyralid populations using egg parasitoids of the genus Telenomus with good results. In the Ivory Coast, for instance, these parasitoids are used to control Eldana saccharina Wlk., Maliarpha separatella Rag., and Scirpophaga melanoclysta Mey., on sugar-cane, rice and maize; in India against Chilo sacchariphagus (Boyer) on sugarcane and in Bolivia against Diatraea rufescens Box and D. saccharalis (F.) on sugarcane. The biology of these egg parasitoids is even more interesting and has a potential for preventing an outbreak of the pest population. Some of them are phoretic upon the adults of their host (Bin \& Johnson 1982).

More than 500 species of Telenomus are currently known. However, biological studies about the genus are few in number when compared to Trichogramma (Polaszek \& Kimani 1990; Honda \& Trjapitzin 1995). There are a number of 
unresolved taxonomic problems at species-level in this genus because of its small size and general morphological uniformity (Nixon 1937 and Polaszek 2001). The taxonomy of the genus has been based on morphological traits. However, these characters may display a great level .of plasticity and do not always reflect the phylogenetic relationships among species.

Molecular techniques provide efficient tools for the study of natural population genetics (Hoy 1994). Random amplified polymorphic DNA polymerase chain reaction (RAPDPCR) has been used to survey mosquito species and population (Kambhampati et al. 1992) and population genetics of parasitoid wasp Diaeretiella rapae (Hymenoptera: Braconidae) (Vaughn \& Antolin 1998). Previously, Landry et al. (1993); Masutti (1994) and Meilin (1999) used RAPD technique for Tricho-gramma species identification. RAPD-PCR is particularly valuable for genomic mapping in species for which little genetic information is available (Hoy 1994) such as the genus Telenomus.

So far, no study has been done on the differentiation between and within Telenomus species in Indonesia. We employed molecular technique to see species differences and to see whether there are genetical variations within the same species from different locations. Our objective was to differentiate four species of Telenomus and five populations of $T$. rowani collected from several locations in Java using the RAPD technique.

\section{MATERIALS AND METHODS}

\section{Sample Collection and Identification}

Egg parasitoids of Telenomus spp. were collected from various crops, e.g soybean, sugarcane and paddy in West Java, Central Java and East Java. Parasitized lepidoptera and hemiptera eggs were collected and brought to the laboratory for subsequent parasitoid development. Identification of parasitoid was based on Nixon (1937), Nishida and Torii (1970)

\section{DNA Extraction}

DNA was extracted using a technique described by Goodwin et al. (1994) with the following modifications. One to three wasps of each Telenomus species and five populations of T. rowani were crushed with a glass rod in $125 \mathrm{ul} \mathrm{CTAB} \mathrm{(2 \% ).} \mathrm{DNA} \mathrm{preparations} \mathrm{were} \mathrm{stored} \mathrm{at}$ $4{ }^{\circ} \mathrm{C}$ in 30 ul distilled water.

\section{PCR Amplification}

PCR was performed using Gene Amp ${ }^{\mathrm{R}}$ PCR System 9700 (PE Applied Biosystem). Ready To Go ${ }^{\text {TM }}$ RAPD bead (Pharmacia Biotech) was used for each PCR reaction. Each of 25 ul reaction mixture contained a RAPD bead, 5 ul of genomic DNA, 5 ul of 25 pmol primer P2 (5' -d[GTTTCGCTCC]-3' ) and 15 ul 
distilled water. PCR condition for the integron was amplified in 45 thermal cycles at $95{ }^{\circ} \mathrm{C}$ for 1 minute, $36{ }^{\circ} \mathrm{C}$ for 1 minute and $72{ }^{\circ} \mathrm{C}$ for 3 minutes. The PCR products were then held at $4{ }^{\circ} \mathrm{C}$ until recovered.

\section{DNA Visualization}

The DNA fragment was separated using an agarose gel. Agarose gel of $1.5 \mathrm{~g}$ was prepared in $100 \mathrm{ml}$ of $1 \mathrm{x}$ TBE (90 mM Tris-Borate buffer, $2 \mathrm{mM}$ EDTA pH 8.0) and then heated until boiling point using microwave.

\section{Electrophoresis}

Eight ul of PCR product was mixed with 2.0 ul of gel-loading buffer (30\% glycerol, $0.25 \%$ bromophenol blue and $0.25 \%$ Xylene Cyanol) and electrophoresed on $1.5 \%$ agarose gel (TBE) at 100 volt for about 2 hours. DNA bands were stained with ethidium bromide and photographed with fast Polaroid film using transluminator UV light. DNA band size was determined by comparing with a 100 base-pair DNA ladder run on gel.

\section{Data Analysis}

The data matrix was constructed with each line in the gel containing the identified species and RAPD-PCR bands were scored 1 if it is present and 0 if absent. A cluster analysis was carried out using the unweighed pair group method with arithmetic means (UPGMA clustering) of similarity coefficient for all pairs of species and population. The phenogram was generated using a computer-based taxonomy program Numerical Taxonomy System, (NTSYS-PC version 2.1) (Rohlf 2000).

\section{RESULTS AND DISCUSSION}

Based on morphological characters, four Telenomus species have been identified, $T$. rowani, T. remits, T. dignus and T. dignoides (Yuliarti 2002). We have screened three primers (Pharmacia Biotech) as follows: PI (5'-d[GGTGCGGGAA]-3'), P2 (5'-d[GTTTCGCTCC]-3') and P3 (5'-d[GTAGA.CCCGT]-3'). The results showed that primer P2 gave the best polymorphic bands. The results of genomic DNA amplification using primer P2 (5' d[GTTTCGCTCC]-3') indicated that the four Telenomus species can be genetically differentiated (Fig. 1). Each species of Telenomus has a unique set of RAPD bands. Several clear and well-amplified bands were used for analysis. The result of the amplification showed that the size range of the bands are between 200 base-pair (bp) and 1500 bp. Two bands approximately 300 and 430 bp seem to indicate the specificity of the genus Telenomus. These two bands are monomorphic bands (Fig. 1). In contrast, the polymorphic bands which indicate the specificity of each species are shown by different band size as seen in Fig.l. 


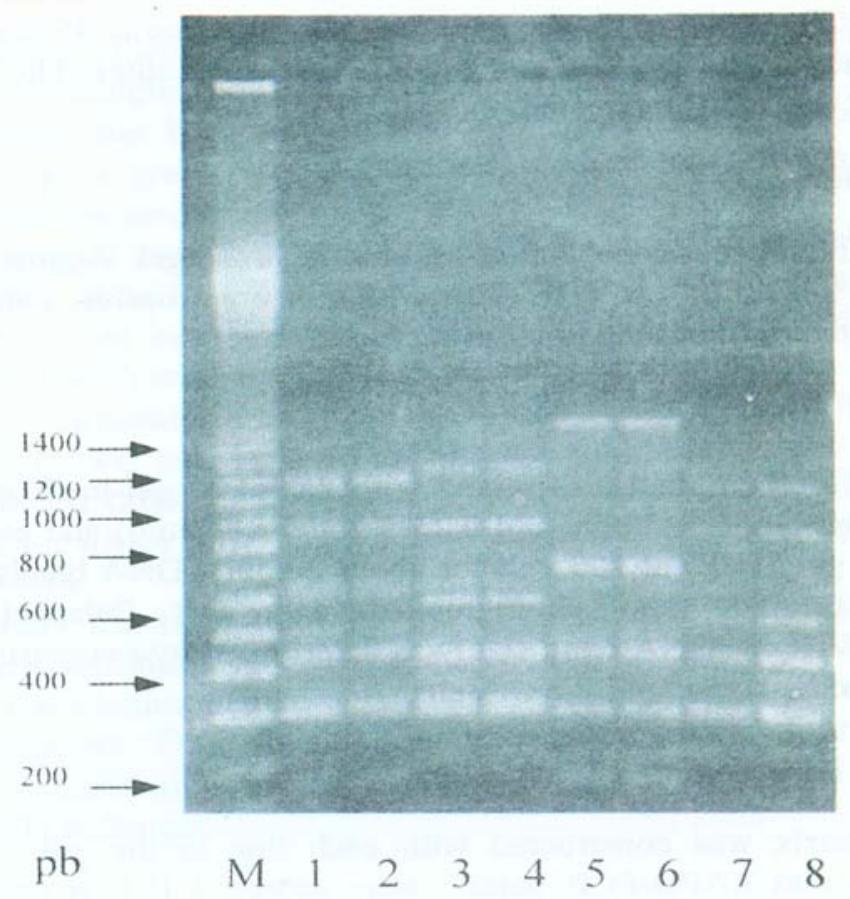

Figure 1. DNA banding patterns generated by RAPD primer P2 (5'-d[GTTTCGCTCC]-3) showing differentiation between species of Telenomus, M, 100 base-pair molecular weight ladder; 1-2, T. rowani; 3-4, T. remus; 5-6, T. dignoides; 7-8, T. dignus.

Fig. 1 shows that each Telenomus species has three specific bands except $T$. dignoides which has only two specific bands. Specific bands of $T$. rowani are estimated to be 650,850 and $1100 \mathrm{bp}$, whereas T. remus are 600, 850 and $1150 \mathrm{bp}$. Unique bands of T. dignoides are estimated to be 700 and $1450 \mathrm{bp}$, whereas T. dignus are 550, 800 and $1050 \mathrm{bp}$.

Although only slight differences occur between each Telenomus species, our results showed that RAPD procedures can reveal species-specific banding pattern that can be used for a rapid and easy identification of Telenomus species. This technique can potentially be very important for identification purposes, since Polaszek and Kimani (1990) stated that due to its smallness, Telenomus spp. are most often difficult to identify correctly which then resulted in confusion and errors in identification. To overcome these difficulties, molecular technologies can be applied to allow the detection of diagnostic markers which are necessary to resolve ambiguities in taxonomical identification and systematics in the genus Telenomus (Polaszek 2001). 
RAPD-PCR has some limitations i.e uncertain reproducibility, fragments of the same size are not necessarily of the same sequence and reveal dominant marker only. Previously, Masutti (1994) and Meilin (1999) used RAPD markers for Trichogramma species identification. Even though RAPD-PCR has its own drawbacks, i.e bands of the same size are not necessarily of the same sequence, these bands are normally inherited as dominant traits. Therefore, RAPD is still useful for generating species-specific markers. Hoy (1994) stated that RAPD-PCR may be able to detect small differences in the genomes of individual insects or mites, different insect populations or species.

In this study we could not find differentiation among the five T. rowani populations by using primer P2 (5 -d[GTTTCGCTCC]-3) (Amersham Pharmacia Biotech), despite the fact that those populations originated from different locations in Java (Fig.2). We found no variations in DNA banding patterns for all populations. In other words, all of the populations revealed the same bands with the same molecular weight and only three bright bands were estimated to be in the range of $300-480 \mathrm{bp}$. There are two interpretations that could be derived from these results. First, the null difference can be due to the limitations of RAPD technique; second, the result reflected real condition of $T$. rowani populations. In this case RAPD-PCR did not allow differentiation of $T$. rowani populations because there are no specific bands that can be detected using this particular primer. However, screening was conducted with only one primer, and it is likely that unique RAPD markers could be found that discriminate among the populations if additional primers are tested. However, these studies can be used as a framework on which to base further studies which are required to fully elucidate species and population of Telenomus.

This result was contrary to previous studies on some populations of Trichogramma evanescens (Masutti 1994); T oidea armigera and T oidea cojuangcoi (Meilin 1999) by using RAPD-PCR in which differentiation among the populations were found. In another study, Vaughn \& Antolin (1998) reported that Diaretiella rapae (Hymenoptera: Braconidae) populations are genetically subdivided into a small spatial scale that corresponds to host-use patterns.

\section{Cluster Analysis}

Cluster analysis based on UPGMA revealed that four Telenomus species formed two groups (Fig. 3). The dendrogram showed that T. remits and T. rowani belong to one cluster, whereas $T$. dignus and $T$. dignoides belong to another group. However, the two groups in this dendrogram were different in coefficient level (Table 1). The dendrogram showed that $T$. rowani was closely related to $T$. remus, whereas $T$. dignus was closely related to $T$. dignoides. However, $T$. remus and $T$. rowani were rather far to $T$. dignus and $T$. dignoides. Masutti (1994) stated that RAPD banding patterns might be informative for the phylogenetic relatedness. In addition, Nixon (1937) reported that T. dignoides was certainly very closely related to T. dignus. 


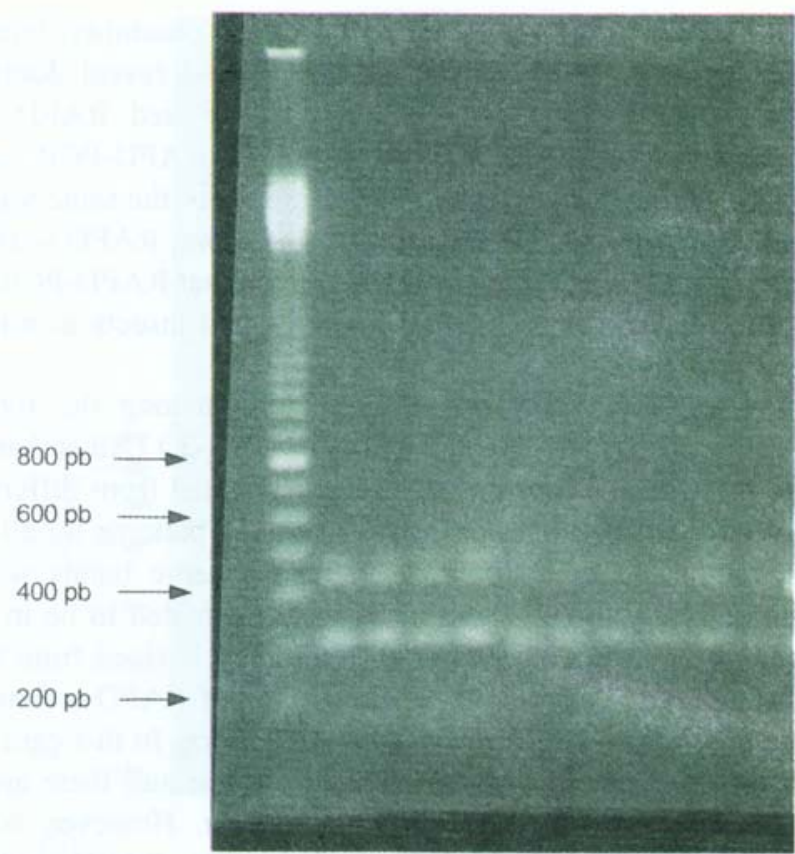

$\begin{array}{llllllllllll}M & 1 & 2 & 3 & 4 & 5 & 6 & 7 & 8 & 9 & 10\end{array}$

Figure 2. DNA banding patterns generated by RAPD primer P2 ( $\left.5^{\circ}-\mathrm{d}[\mathrm{GTTTCGCTCC}]-3\right)$ showing five populations of $T$. rowani, M, 100 base-pair molecular weight; 1-2, from Subang, 3-4 from Bantar Kemang (Bogor), 5-6, from Sindang Barang (Bogor); 7-8, from Bantul (Yogyakarta); 9-10, from Purwokerto (Central Java)

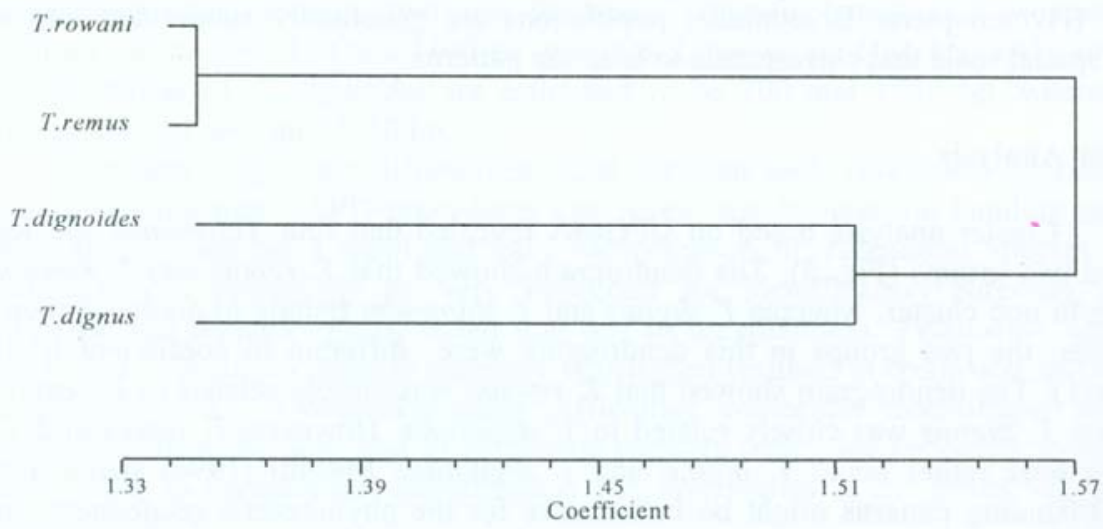

Fig. 3 Dendrogram based on RAPD patterns marker from four species of Telenomus 
Table 1. A distance matrix of four species of Telenomus

\begin{tabular}{lcccc}
\hline \hline OUT $^{\sharp}$ & T. rowani & T. remus & T. dignoides & T. dignus \\
\hline T. rowani & 0 & & & \\
T. remus & 1,3093 & 0 & 0 & 0 \\
T. dignoides & 1,5457 & 1,5457 & 1,5457 & 0 \\
T. dignus & 1,6036 & 1,6036 & & \\
\hline
\end{tabular}

"OUT= Operation Taxon Unit $=$ Species.

\section{REFERENCES}

Bin F, Johnson NF. 1982. Some new species of Telenomus egg parasitoids of tropical pyralid pests. Redia 65: 229-252 (+ 5 plates).

Goodwin DH, Xue BG, Kuske CR, Sears MK. 1994. Amplification of plasmid DNA to detect plant pathogenic mycopiasma like organism. Ann Appl Biol 36. 124-127.

Johnson NF. 1984. Systematics of Nearctic Telenomus : Classification and revisions of the podisi and phymatae group. Bull of the Ohio Biological Survey 6 (3): 1-113.

Honda JY, Trjapitzin SV. 1995. A species description and biological comparison between a new species of Telenomus Haliday (Hymenoptera: Scelionidae) and Trichogramma platneri Nagarkatti (Hymenoptera: Trichogrammatidae): Two egg parasitoids of Sabulodes aegrotata (Guenee) (Lepidoptera: Geometridae). Pan Pacific Entomol 71 (4): 227-236.

Hoy MA. 1994. Insect molecular genetics. An introduction to principle and applications. San Diego. Academic Press.

Kambhampati S, Black IV WC, Rai KS. 1992. Random amplified polymorphic DNA of mosquito species and population (Diptera: Culicidae). Techniques statistical analysis and applications. J Med Entomol 29 (6): 939-945.

Landry BS, Dextraze L, Boivin G. 1993. Random amplified polymorphic DNA markers for DNA fingerprinting and genetic variability assessment of minute parasitic wasp species (Hymenoptera: Mymaridae and Trichogrammatidae) used in biological control programs of phytophagous insects. Genome 36: 580-587.

Masutti FV. 1994. Molecular identification and phylogeny of parasitic wasp species (Hymenoptera: Trichogrammatidae) by mitochondrial DNA RFLP and RAPD markers. Insect Mol Biol 3 (4): 229-237.

Meilin A. 1999. Keragaman karakter morfologi dan genetika populasi parasitoid telur, Trichogramma spp. and Trichogrammatoidea spp. (Hymenoptera: Trichogrammatidae) dari daerah geografis yang berbeda di pulau Jawa. (tesis). Bogor: Program Pascasarjana IPB.

Nishida T, Torii. 1970. A handbook of field methods for research on rice stem-borers and their natural enemies. London. International Biological Programme. 
Nixon GEJ. 1937. Some Asiatic Telenominae (Hymenoptera: Proctotrupoidea). Ann \& Mag Nat Hist 10 (20): 444-475.

Polaszek A, Kimani SW. 1990. Telenomus species (Hymenoptera: Scelionidae) attacking eggs of pyralid pest (Lepidoptera) in Africa: a review and guide top identification. Bull of Entomol Res 80: 57-71.

Polaszek A. 2001. An overview of the parasitoids ofSpodoptera exigua. Workshop on the Management ofSpodoptera spp. in Vegetable Crops. Kuala Lumpur. 14-16 March 2001.

Rohlf FJ. 2000. NTSYS pc, Numerical taxonomy and multivariate analysis system, version 2.1. Exeter Software. New York.

Vaughn TYT, Antolin MF. 1998. Population genetics of an opportunistic parasitoid in an agricultural landscape, J Heredity 80: 152-162.

Yuliarti N. 2002. Karakter morfologi dan molekuler parasitoid telur, Telenomus spp. (Hymenoptera: Scelionidae) dari beberapa daerah di Jawa. (tesis). Bogor. Program Pascasarjana IPB. 